\title{
Risk factors, diagnosis, and management of posttransplant lymphoproliferative disorder: improving patient outcomes with a multidisciplinary treatment approach
}

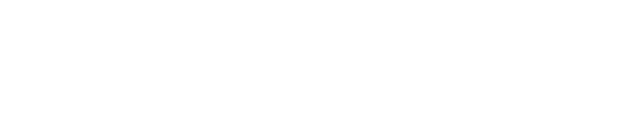

\author{
Kinga Ligeti \\ Lutz P Müller \\ Carsten Müller-Tidow \\ Thomas Weber \\ Department of Hematology and \\ Oncology, University Hospital Halle \\ (Saale) and Martin-Luther-University \\ Halle-Wittenberg, Halle (Saale), \\ Germany
}

\begin{abstract}
Posttransplant lymphoproliferative disease (PTLD) is a major complication after solid organ transplantation and allogeneic hematopoietic stem cell transplantation. The spectrum of PTLD ranges from benign hyperplasia to malignant lymphoma, representing one of the most relevant malignancies in these patients. Most PTLDs are driven by latent Epstein-Barr virus infections. The backbone of treatment is reduction of immunosuppression. Further treatment depends on the type of PTLD and the type of transplantation. A multidisciplinary approach involving transplant team, hematologists, and other disciplines is crucial for the diagnosis and treatment of PTLD and for concurrent preservation of the transplant function. In this study, known pathomechanisms, risk factors, preemptive management, and especially emerging treatment algorithms in PTLD were reviewed.
\end{abstract}

Keywords: lymphoproliferative disease, Epstein-Barr virus, management, rituximab, preemptive therapy

\section{Introduction}

Posttransplant lymphoproliferative disease (PTLD) represents a spectrum of clinical and morphological heterogeneous lymphoid proliferations ranging from benign reactive hyperplasia to malignant lymphoma. PTLD develops in the setting of immunosuppression after solid organ transplantation (SOT) or allogeneic hematopoietic stem cell transplantation (HSCT).

It is one of the most common malignancy after both transplant settings, with an incidence ranging from $1 \%$ to $20 \%$. It is usually associated with poor prognosis, with a 5 -year overall survival rate of $20 \%{ }^{1,2}$ Its occurrence depends on the type of transplant received, the type of immunosuppression, its intensity and duration, and the age of the recipient. ${ }^{1}$

\section{Pathogenesis and classification}

The majority of PTLD is Epstein-Barr virus (EBV) associated. Infection of B lymphocytes with EBV results in either viral replication, triggering cell death, or in latency. In the latency phase, the viral genome adopts an episomal configuration and expresses only a few proteins: the EBV nuclear antigens - EBNA-1, EBNA-2, EBNA-3A, EBNA3B, EBNA-3C, and EBNA-LP; and the latent membrane proteins - LMP1, LMP2, and LMP3. LMP1 is considered as the main oncogenic protein, and it acts like CD40, a member of the tumor necrosis factor receptor superfamily. ${ }^{3}$ Through the activation
Correspondence: Thomas Weber Department of Hematology and Oncology, University Hospital Halle (Saale) and Martin-Luther-University Halle-Wittenberg, Ernst-Grube-Str 40, 06120 Halle (Saale), Germany

Tel +49345 5577285

Fax +49 3455577242

Email thomas.weber@uk-halle.de 
of several downstream signaling pathways, LMP1 leads to the expression of anti-apoptotic proteins and cytokines (eg, BCL2 and interleukin 1), providing growth and differentiation signals to B cells independent of T-helper cell function. ${ }^{4}$

EBV-negative cases of PTLD are increasing in number. ${ }^{5}$ The etiology and pathogenesis of these lymphomas are not well understood. There are several hypotheses that explain the pathogenic mechanisms of EBV-negative PTLD: chronic immune stimulation by the graft, hit-and-run EBV infection, or other infectious agents, leading to the accumulation of genetic alterations and substituting the oncogenic effects of EBV. ${ }^{6-8}$ Comparison of EBV-positive and EBV-negative posttransplant (diffuse large B cell lymphoma) DLBCL showed that the latter contains more recurrent genomic lesions. ${ }^{9}$ Gene expression profiling studies have shown that EBV-negative PTLD are biologically distinct from their EBV-associated counterparts and more similar to EBV-negative de novo lymphomas in immunocompetent host. ${ }^{10,11}$

Chromosomal and comparative genomic hybridization analyses show chromosomal aberrations in $\sim 50 \%$ of PTLD cases. ${ }^{12-15}$ Mutations in BCL6, MYC, PAX5, PIM1, RHOH (4p13), or NRAS (1p13) are recurrent in PTLD. They may be related to somatic hypermutation occurring naturally in $\mathrm{B}$ cells. ${ }^{16,17}$ Inactivation of tumor suppressor genes (eg DAPK1 and $M G M T$ ) has also been described. ${ }^{8,10,18}$

The majority of PTLDs are of B-cell origin. T-cell or NK-cell PTLDs are rare, and EBV association can be identified only in $\sim 30 \%$ of cases. ${ }^{19}$ In most B-cell PTLD, CD20 is expressed, although it has been shown that both polymorphic and monomorphic PTLDs have higher incidence of lack of CD20 as compared with de novo B-cell lymphoma. ${ }^{20}$ PTLDs after SOT are of recipient origin, whereas PTLDs following HSCT are almost exclusively of donor origin and develop early after $\mathrm{HSCT}^{21,22}$

The 2008 WHO classification of lymphoid neoplasms recognizes four major histopathologic subtypes of PTLD: early hyperplastic lesions, polymorphic lesions (which may be polyclonal or monoclonal), monomorphic lesions (non-Hodgkin-type lymphomas), and classic Hodgkin-type lymphomas (Table 1). ${ }^{23}$

Early lesions are often polyclonal and preserve the normal architecture of the affected tissues. They are further subdivided into infectious mononucleosis-like paracortical hyperplasia and plasmacytic hyperplasia. If untreated, a neoplastic clone can appear and transition to one of the more advanced subtypes of PTLD can occur. ${ }^{23}$

In polymorphic PTLD, a mixture of small to large lymphocytes and immunoblasts can be seen. These cells
Table I WHO classification of PTLD

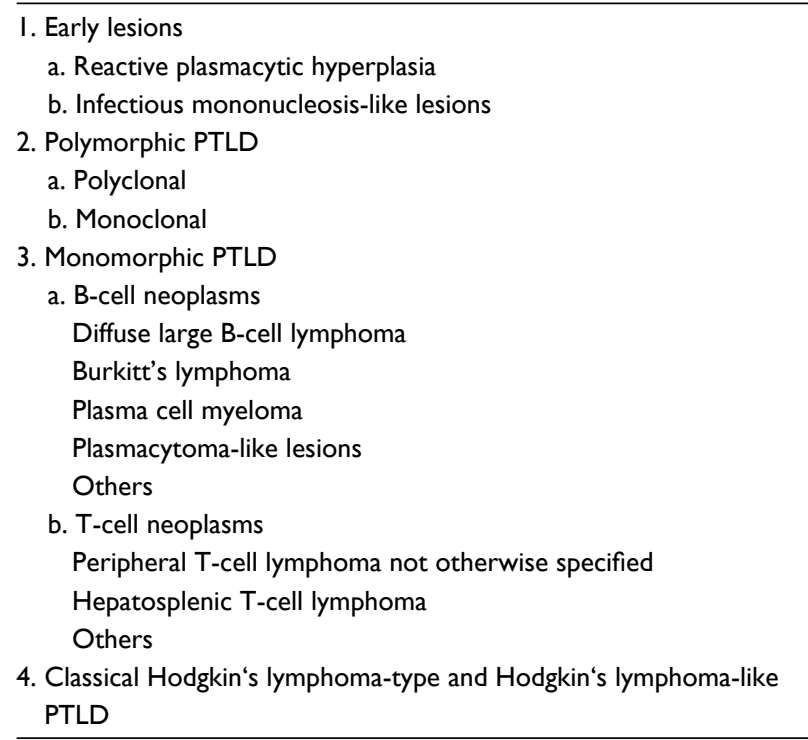

Abbreviations: PTLD, posttransplant lymphoproliferative disease; WHO, World Health Organization.

include EBV-infected monoclonal B cells as well as reactive T lymphocytes. This lymphoplasmacytic proliferation is destructive but does not fulfill the strict criteria of malignant lymphoma. ${ }^{24-26}$

In monomorphic PTLD, atypical lymphocytes resemble the conventional histopathologic types of B-cell malignancy (eg, diffuse large B-cell lymphoma, Burkitt lymphoma, anaplastic large cell lymphoma, and plasmocytoma). The vast majority of cases are associated with EBV infection/ reactivation. These are more likely to occur late after transplantation, and they resample de novo B-cell lymphoma. Classical Hodgkin lymphoma-type PTLD is rare and makes the diagnosis of Hodgkin lymphoma-like polymorphic PTLD challenging because of a clear overlap..$^{27,28}$

\section{Epidemiology and risk factors}

After HSCT, the overall incidence of PTLD is rather low, ranging from $1 \%$ to $3 \%$. The majority of PTLDs occurs early, within the first year of HSCT. ${ }^{29,30}$ PTLD rates are increased with the use of myeloablative conditioning regimen, in vivo or in vitro T-cell depletion with antithymocyte globulin (ATG) or monoclonal CD3 antibodies. The presence of GvHD and its treatment with ATG or other anti-T-cell antibodies also increases the risk, especially of late onset PTLD. ${ }^{30,31}$

After SOT, PTLD is one of the most common malignancy, following nonmelanoma skin cancer. ${ }^{32-34}$ The cumulative incidence after 5 years ranges from $1 \%$ to $10 \%$, with highest rates up to $33 \%$ in small bowel and multivisceral transplantation (Table 2). ${ }^{35,36}$ Major risk factors for developing PTLD 
Table 2 Cumulative I- and 5-year incidence of PTLD by transplanted organ as reported in the 2010 OPTN/SRTR Annual Report

\begin{tabular}{llllll}
\hline Organ & Pediatric & & Adult & \\
\cline { 2 - 3 } \cline { 5 - 6 } & After I year (\%) & After 5 years (\%) & & After I year (\%) & After 5 years (\%) \\
\hline Lung/heart-lung & 4 & 16 & 1 & 1.5 \\
Liver & 2.1 & 4.7 & 0.25 & 1.1 \\
Pancreas & N/A & N/A & 2.3 & 2.3 \\
Heart & 1.6 & 5.7 & 0.3 & 0.7 \\
Kidney & 1.3 & 2.4 & $<0.2$ & 0.6 \\
\hline
\end{tabular}

Note: Data from Organ Procurement and Transplantation Network (OPTN) and Scientific Registry of Transplant Recipients (SRTR). ${ }^{35}$

Abbreviations: N/A, not available; OPTN/SRTR, Organ Procurement and Transplantation Network/Scientific Registry of Transplant Recipients; PTLD, posttransplant lymphoproliferative disease.

Table 3 Risk factors of PTLD

\begin{tabular}{l}
\hline Risk factors \\
\hline EBV seronegativity at the time of transplantation \\
Active primary EBV infection at the time of transplantation \\
Variants of $L M P I$ gene sequence \\
T-cell depletion \\
Immunosuppressive drug regimen and intensity \\
Type of transplanted organ \\
Age (children and older patients) \\
CMV coinfection \\
Acute or chronic graft versus host disease \\
Second transplant \\
Prior splenectomy \\
HLA type \\
Extent of HLA mismatch
\end{tabular}

Abbreviations: CMV, cytomegalo virus; EBV, Ebstein-Barr virus; HLA, human leukocyte antigen; LMPI, latent membrane protein I; PTLD, posttransplant lymphoproliferative disease.

after SOT or HSCT are age at transplantation, pretransplant EBV mismatch, type of transplanted organ, T-cell depletion, and immunosuppression (Table 3).

Landgren et $\mathrm{al}^{31}$ conducted a large study of 21,686 HSCT patients and identified some major risk factors for developing PTLD after transplant. The most important risk factor was selective T-cell depletion and ATG use for prophylaxis or treatment of GvHD. Other significant risk factors were age $>50$ years, second HSCT, human leukocyte antigen (HLA) mismatch, and unrelated donor. The incidence of PTLD was low $(0.2 \%)$ in the absence of risk factors, while an increased incidence $(8.1 \%)$ was noticed in the subgroup of patients with more than three of the described risk factors. ${ }^{31}$

Regimen of immunosuppression and intensity play a very important role for the development of PTLD after HSCT and SOT. It appears that the most important factor is the degree of T-cell immunosuppression, as T-cell-specific immunity against EBV is impaired with increased impairment of T-cell function. Thus, ATG, anti-CD3 monoclonal antibodies, fludarabine, azathioprine, and other agents causing profound T-cell depletion significantly increase the risk of PTLD with a relative risk increasing up to $25 \%$ compared with the normal population. ${ }^{37-42}$ Conditioning with alemtuzumab also increases the risk of PTLD, but the risk is much lower as seen in selective T-cell depletion. ${ }^{31,43,44}$

In some retrospective analyses, tacrolimus compared with ciclosporin A in SOT patients increased the risk of PTLD, whereas other analyses did not show an increased risk with tacrolimus-based immunosuppression. ${ }^{37,40,43,45}$ Adding mycophenolate mofetil to a double immunosuppressive regimen was not associated with a further increase in the incidence of PTLD. ${ }^{46,47}$

Immunosuppression with mammalian target of rapamycin inhibitors might have a positive effect on PTLD incidence. In experimental studies, mammalian target of rapamycin inhibitors like everolimus and sirolimus have been shown to inhibit transformed cells, such as EBV-transformed B cells. ${ }^{48,49}$ The sirolimus predrug temsirolimus represents a very effective treatment modality in mantle cell lymphoma supporting the B-cell inhibiting potential of these drugs. ${ }^{50}$ However, the prevalence of PTLD under immunosuppression with mammalian target of rapamycin inhibitors needs to be defined in the settings of HSCT or SOT.

In SOT, HLA type may influence the ability of the immune system to present foreign epitopes. For example, HLA-A3 allele expression in recipient and/or donor was associated with a sevenfold risk for PTLD in patients after lung transplant. ${ }^{51}$ Mismatches at HLA-B loci might also confer greater risk for PTLD after renal transplantation. ${ }^{52,53}$ HLA-A1 carriers seem to be also at greater risk of developing EBV-related PTLD, with highest incidence being seen in HLA-A1 homozygotes, whereas HLA-A2 homozygotes are at lower risk. ${ }^{54}$

\section{Clinical features}

The clinical signs in PTLD are nonspecific and variable, making its diagnosis challenging. Involvement of the allografted tissue can cause declining organ function; it may be the initial presenting symptom. ${ }^{55-57}$ For example, kidney transplant recipients with allograft involvement often present with renal dysfunction or signs of ureteral obstruction (ie, hydronephrosis) and fever. ${ }^{56,58}$ 
Further signs of PTLD depend on the involved organs and therefore can be highly variable. Signs of PTLD can range from isolated hepatitis, lymphoid interstitial pneumonitis to infectious mononucleosis-like syndrome with fever, peripheral lymphadenopathy, and hepatitis. The gastrointestinal tract is also frequently involved; signs and symptoms such as diarrhoea and bleeding may also lead to the diagnosis of PTLD. Less common sites of involvement are the oral cavity, skin, and subcutis.

Other signs that should trigger awareness of PTLD may be more unspecific such as unexplained fever or lymphadenopathy ${ }^{24}$ or hemophagocytic lymphohistiocytosis, but also more localized symptoms such as headache or confusion in case of central nervous system (CNS) involvement. ${ }^{59,60}$ Of all PTLD cases, primary CNS (PCNS) involvement occurs in $\sim 5 \%-15 \%$, much more frequent as the novo PCNS lymphoma. ${ }^{61}$ The most fulminant presentation is a diffuse systemic disease that resembles septic shock. ${ }^{24}$ In laboratory tests, cytopenia, elevated lactate dehydrogenase, or detection of monoclonal protein can indicate manifest PTLD. ${ }^{62}$

\section{EBV monitoring and preemptive therapy}

Quantitative polymerase chain reaction (PCR) is recommended for detecting and measuring EBV-DNA load in peripheral mononuclear blood cells, plasma, or whole blood. ${ }^{63}$ It is considered as the method of choice in the early phase after HSCT. In HSCT, monitoring of EBV-DNA load is strongly recommended in all patients except in those with non-T-cell depleted matched related donor HSCT without EBV IgG sero-mismatch. ${ }^{30,53}$ Weekly EBV-PCR screening should start at day of HSCT for at least 3 months after HSCT. Patients with haploidentical HSCT, patients with GvHD, or patients who experienced EBV reactivation should be monitored longer. Also in SOT, monitoring of EBV viral load by PCR identifies patients at risk for developing PTLD. However, an internationally excepted cutoff of EBV-DNA burden for predicting increased risk for the development of PTLD is still not established. There is no consensus at which threshold one should initiate preemptive treatment. ${ }^{64}$ Of note, a negative EBV-DNA load makes an EBV-associated PTLD less likely. ${ }^{65,66}$

In an ongoing PTLD, the dynamic of EBV-DNA load in peripheral blood has been shown to correlate with the patient outcome. Declining levels are seen in clinical and radiological resolution of PTLD, whereas an increase in the viral DNA load is seen in progressive disease. ${ }^{67,68}$ Thus, measuring circulating EBV levels at regular base represents an effective, noninvasive tool for the assessment of tumor burden and treatment efficacy. ${ }^{69}$ In PTLD patients receiving anti-CD20 antibody, a rapid decline in EBV-DNA load is seen. This decline is independent of clinical response and is mainly due to the clearance of B cells. ${ }^{70}$ Therefore, caution should be taken during interpretation of EBV-DNA burden in peripheral blood under B-cell depleting therapies. Once EBV reactivation occurs and PTLD is suspected, further investigations such as imaging studies to identify lymph node enlargement or organ involvement should be undertaken to exclude manifest PTLD, and preemptive measures should be made.

The type and dose of immunosuppressive therapy being the most modifiable risk factor, strategies to prevent EBV-associated PTLD target the recovery of the immune surveillance, especially T-cell function, by adjusting the immunosuppression to control the EBV-infected B-cell proliferation.

Reduction of immunosuppression (RIS) should be the initial step. In order to minimize the drawback consisting of increased risk of graft rejection in SOT recipients or graft versus host disease in HSCT patients, RIS should always be performed in close and multidisciplinary coordination with the transplant team..$^{71}$

\section{Preemptive rituximab}

Styczynski et $\mathrm{al}^{64}$ reported in their review a success of $90 \%$ (306/341 patients) in preventing EBV-associated PTLD after preemptive therapy of EBV-viremia with rituximab in patients after HSCT. Preemptive rituximab treatment of PTLD is implemented in $\sim 80 \%$ of European HSCT centers. ${ }^{72}$ Application of $1-2$ doses of $375 \mathrm{mg} / \mathrm{m}^{2}$ rituximab is common.

Choquet et $\mathrm{al}^{2}$ conducted a prospective single-center study on patients $(n=299)$ after heart transplantation, treated with the same immunosuppressive regimen, and monitored by repetitive EBV-DNA load measurements in peripheral blood, setting an internal cutoff and guiding their therapy according to the EBV levels. As the first step, immunosuppression was tapered if EBV viral load was $>50,000$ copies/mL or EBV primary infection was present. If no response was observed, patients received preemptive rituximab. In comparison with the historical data, this study showed an effective prevention of EBV-associated PTLD by closely monitoring the EBV load and taking preemptive measures. ${ }^{2}$

The limitation of this approach is the induction of B-lymphocyte depletion for $\sim 6$ months, leading to infection susceptibility. It does not restore the cellular immunity against EBV and thus does not provide long-term control of 
EBV-triggered B-cell proliferation. ${ }^{73}$ Thus, in SOT patients, who are likely to take immunosuppressive drugs for life, repeated $\mathrm{EBV}$ reactivation must be considered upon recovery of B cells.

\section{Preemptive adoptive immunotherapy}

Adoptive transfer of autologous or allogeneic EBV-specific cytotoxic T lymphocytes (EBV-CTLs) has been investigated in several studies both in preemptive and in therapeutic settings with positive results. ${ }^{7-78}$ These specific $\mathrm{T}$ lymphocytes are isolated from either EBV seropositive stem cell donors or third-party donors and are expanded in vitro.

After SOT, autologous EBV-CTLs have prevented PTLD in high-risk patients. ${ }^{76,77}$ After HSCT, promising results were obtained in the preemptive setting: the use of donor EBVspecific CTLs prevented PTLD in all patients. ${ }^{75,78}$ Styczynski et $\mathrm{al}^{64}$ found an overall response rate (ORR) of $94.1 \%$.

The limitation in most clinical settings are the duration of the ex vivo expansion of these specific cells of 3-4 weeks and the high costs. Strategies to rapidly generate EBV-specific CTLs have been developed, such as overnight stimulation of donor CTLs with EBV-specific peptides and selection of antigen-specific T-cells or implementation of a third-party bank with HLA-type EBV-CTLs. ${ }^{79,80}$

\section{Preemptive antiviral therapy}

Whether antiviral agents (acyclovir and ganciclovir), primarily used as cytomegalovirus prophylaxis, prevent PTLD development is also being discussed. The EBV-transformed cells do not express thymidine kinase, which is required for metabolization of the antiviral drug in the active form. It is not clear whether the ongoing active EBV replication also has a role in the development of PTLD. Funch et al retrospectively reported a strong association between freedom from PTLD and prophylactic aciclovir or ganciclovir administration in 100 pediatric patients after liver transplant compared with 375 matched controls. However, except a few reported cases of PTLD which failed to respond to conventional therapy, there is insufficient data and evidence of efficacy and safety of antiviral drugs outside clinical trials..$^{71,81}$

\section{Diagnosis}

Once PTLD is suspected, histopathological examination with adequate immunohistochemical staining of the specimen is essential to confirm the diagnosis of PTLD and for the appropriate classification. ${ }^{23}$ Thus, obtaining adequate material by core or excision biopsy of tumor tissue is fundamental. Fine needle aspiration should only be performed in case of no other option, and flow cytometric immunophenotyping has to be performed in addition.

One recommended basic immunohistochemistry panel includes staining against CD3, CD5, CD10, BCL6, BCL2, IRF4/MUM1, CD20, CD79b, PAX5, Ki67, and kappa and lambda light chains. Under certain circumstances, further evaluation (ie, ALK) may be needed.$^{82}$

EBV association should be determined in every tissue sample. It can be detected by immunohistochemistry for LMP1. This method is sufficient for Hodgkin lymphoma, because this lymphoma expresses the latency type 2 . In situ hybridization targeting EBV-encoded RNA is more sensitive than immunohistochemistry and is recommended if EBV LMP1 is negative. ${ }^{83}$ High-grade lymphomas frequently do not express LMP1; therefore, EBV-encoded RNA in situ hybridization is required in these cases. ${ }^{84}$

The detection of EBV DNA in blood is not a diagnostic criterion for EBV-associated PTLD and cannot replace tissue biopsy. ${ }^{64}$

The initial pretreatment work-up should include:

- Physical examination and evaluation of performance status.

- Baseline blood chemistry (CBC with differential, metabolic panel, LDH) and virology (human immunodeficiency virus, hepatitis $\mathrm{B}$ virus, and hepatitis $\mathrm{C}$ virus).

- EBV viral load by quantitative PCR in peripheral blood.

- Assessment of the function of the transplanted organ, most appropriately directed by the transplant physician.

- Completion of staging according to the Ann Arbor classification with imaging tests.

- Echocardiography if therapy with anthracycline/anthracenedione-containing regimen is being considered.

As for other fluorodeoxyglucose avid lymphomas, ${ }^{18} \mathrm{~F}$-fluorodeoxyglucose-PET/CT is standard in pretreatment evaluation and response assessment in PTLD. ${ }^{85-88}$ Due to possible fatal complications of chemotherapy, comorbidities, performance status, and life expectancy should be assessed for all patients. Currently, there are no validated scores available for the assessment of comorbidities or outcome of patients with PTLD. However, scores and prognostic indices developed for comorbidity assessment in SOT and HSCT, such as hematopoietic cell transplant-comorbidity index (HCT-CI), Charlson Comorbidity Index, Adult Comorbidity Evaluation-27 (ACE-27), and the Eastern Cooperative Oncology Group (ECOG) scale of performance status measuring the impact of the disease on a patient's daily living, are reasonable options to objectivate the patients' status. ${ }^{89}$ 
According to the clinical presentation, some patients may need bone marrow examination, imaging of CNS, and lumbar puncture. Staging of PTLD should be done according to the Ann Arbor staging system. ${ }^{82}$ The International Prognostic Index can be used as a reliable predictor of outcome in patients with PTLD ${ }^{90}$ In the analysis of the cohort of the international phase II PTLD-1 trial, Trappe et al found that the most important prognostic factors that correlated with the outcome and overall survival, respectively, where ECOG, age, response to rituximab, and thoracic involvement. In this study, ECOG $>2$ was associated with treatment-related mortality (TRM). They also showed that the International Prognostic Index score has practical advantages and, as mentioned earlier, is a reliable predictor of outcome. ${ }^{91,92}$

\section{Management and outcome}

The management of PTLD is intended to be curation of this life-threatening disease without jeopardizing the function of the allograft. The main aims of the therapy are to restore cellular immunity in a sequential approach and if necessary to reduce the tumor burden. ${ }^{71,93}$ Due to the heterogeneity of PTLD, treatment recommendations are mainly based on small, mostly retrospective studies. Thus, although guidelines have been published, there is no consensus treatment model.

Diagnosis, classification, and management of PTLD are very challenging due to nonspecific clinical manifestation, heterogenic pathological presentation, and lack of treatment algorithms. Treatment of PTLD also needs to take into account comorbidities and functional impairments of other organs due to long-lasting organ dysfunction prior to SOT and due to aggressive chemotherapies prior to HSCT. A management plan should be agreed by a core multidisciplinary team of experienced physicians, which should include transplant physicians, hemato-oncologists, histopathologists, and radiologists with particular experience of treating solid organ transplant patients and aggressive lymphoproliferative disorders. In some cases, the team may require input from transplant surgeons, radiation oncologists, microbiologists, and palliative care team.

Treatment approaches depend on the PTLD subtype, the type of transplantation, and the performance status of the patient. RIS should be the first step whenever feasible. As mentioned earlier, early lesions are characterized by polyclonality with no signs of malignancy. RIS may be a sufficient treatment strategy in this early phase.

Polymorphic and monomorphic lesions represent the continuum of the disease. However, polymorphic lesions are less aggressive. Thus, adding only rituximab in CD20-positive
PTLD is feasible, avoiding unnecessary toxicities. Monomorphic lesions necessitate a more aggressive approach and a combination of rituximab (if CD20-positive) with chemotherapy according to the histological findings. In light of these three major factors - PTLD subtype, patient's performance status, and type of transplant - a sequential approach is preferred by most experts. The treatment algorithm used in our center is given in Figure 1.

Outcome of PTLD also depends on the aforementioned major factors. In one large case analysis conducted by Styczynski et al, ${ }^{94}$ patients with high-risk HSCT showed an overall mortality rate due to PTLD of $30 \%$. The probability of overall survival at 3 years was $47.3 \%{ }^{94}$ Among patients with PTLD after SOT, a 3-year overall survival was $62 \%$ and the 3 -year progression-free survival was $57 \% .{ }^{95}$

\section{RIS}

First step of treatment for all forms of PTLD is the RIS. ${ }^{71,96-98}$ Before RIS is initiated, the consequence of transplanted organ loss has to be assessed together with the transplant physicians. In patients, in whom immunosuppression cannot be reduced due to potentially fatal loss of the transplant organ, alternative therapies should be promptly initiated.

For the majority of patients, once PTLD is suspected or diagnosed, immunosuppression can be reduced to the lowest tolerated levels (regarding the function of the graft usually by $25 \%-50 \%$ of baseline of immunosuppressive treatment and $50 \%-75 \%$ of baseline in heart or lung SOT) under the guidance of the transplant team. Importantly, RIS without concomitant immunosuppressive chemotherapy leads to acute allograft rejection in $\sim 40 \%$ of patients. ${ }^{98}$

A response to RIS is usually seen within 2-4 weeks and can be achieved in up to $45 \% .{ }^{98}$ With $10 \%$ clinically meaningful responses, this rate is much lower in studies analyzing only monomorphic PTLD. ${ }^{97,99,100}$ If the PTLD completely resolves with RIS, no further treatment may be required. After HSCT, RIS seems to be less efficient compared with SOT.

Waiting for response to RIS is clinically often not feasible, especially in patients with known adverse features associated with poor response to RIS such as raising LDH under RIS, organ dysfunction, and multiorgan involvement. ${ }^{97}$

Further therapy should be promptly initiated if clinical and histological findings suggest progressive disease or if the tumor fails to respond within 3-4 weeks after the initiation of RIS. ${ }^{71}$ In a phase II prospective study, Swinnen et a ${ }^{99}$ evaluated a sequential approach to therapy in 16 evaluable patients after SOT. If no complete remission (CR) was achieved after RIS, further therapy (in this case interferon 


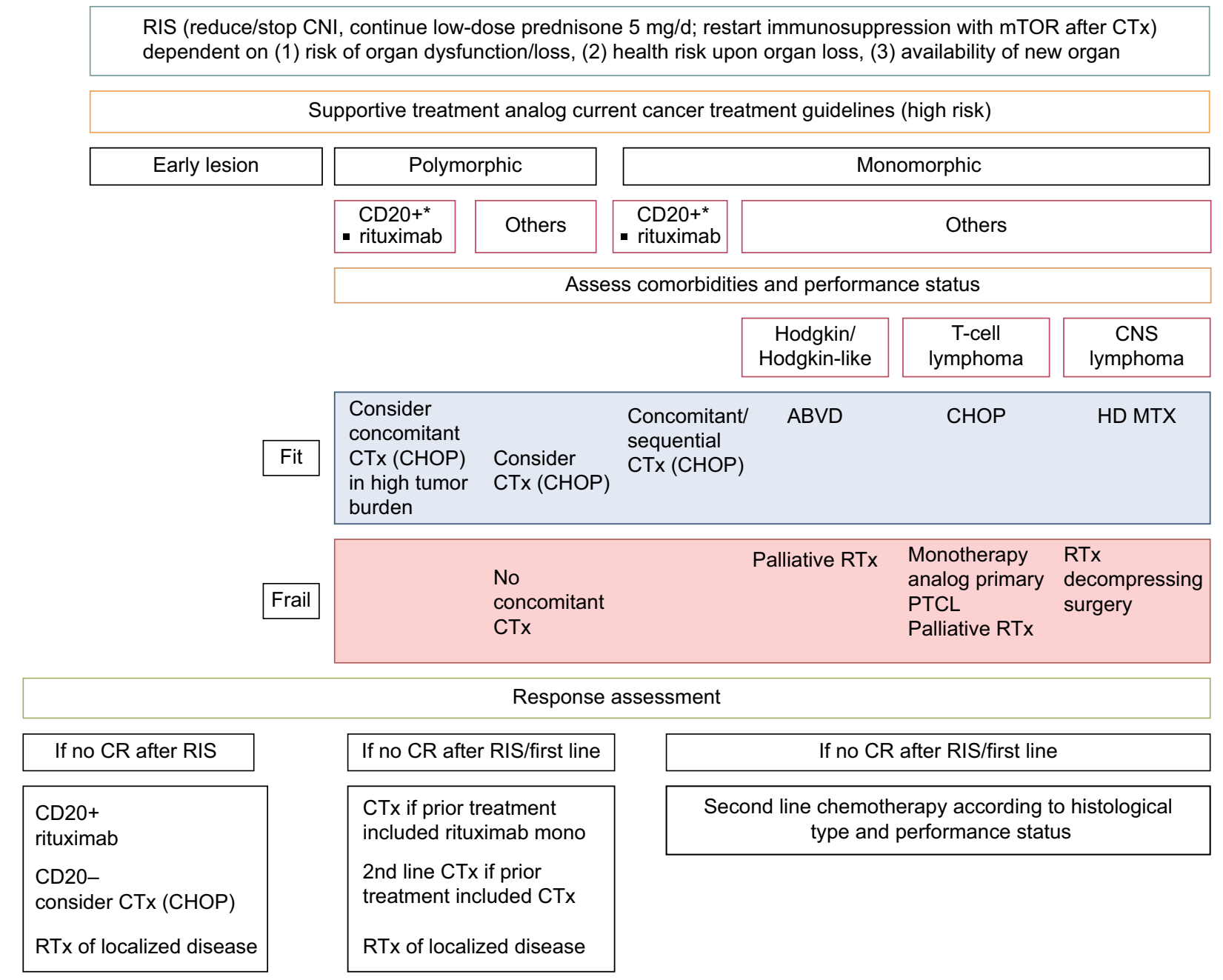

Figure I Treatment algorithm of PTLD.

Notes: In patients who relapse late after 2 years, the initial treatment should be repeated. In patient who relapse early or are refractory, we recommend the carboplatin/ etoposide regimen. *The category of CD20+ PTLD refers to CD20-positive non-Hodgkin lymphomas including Burkitt's lymphoma.

Abbreviations: ABVD, adriamycin/bleomycin/vinblastine/dacarbazine; CHOP, cyclophosphamide/doxorubicin/vincristine/prednisolone; CNI, calcineurin inhibitor; CNS, central nervous system; CR, complete remission; CTx, chemotherapy; HD MTX, high-dose methotrexate; mTOR, mammalian target of rapamycin; PTCL, peripheral T-cell lymphoma; RIS, reduction of immunosuppression; RTx, radiation therapy.

alfa) was given. If no CR was achieved further, multiagent chemotherapy was applied. Only one patient achieved partial remission after RIS. Therapy with interferon alfa resulted in one $\mathrm{CR} ; 67 \%$ achieved $\mathrm{CR}$ after chemotherapy. The regimen did not contain rituximab. ${ }^{99}$

When combining RIS with rituximab in CD20-positive PTLD, PTLD resolved in $84 \%$ of cases. A remarkable finding is that rituximab alone without RIS-induced remission is in only $61 \%$. Prompt RIS at the time of PTLD diagnosis was an independent prognostic factor for survival from PTLD and also for OS with a 2.8 -fold risk reduction of death. ${ }^{94}$

\section{Rituximab}

Adding rituximab increases ORR with tolerable toxicities, thus our approach is to initiate rituximab parallel to RIS for
CD20-positive poly- or monomorphic PTLDs. Rituximab may be administered as single agent or in combination (concurrent, sequential) with chemotherapy.

Several prospective phase II studies and retrospective analyses have confirmed the efficacy of rituximab therapy as single agent in CD20-positive PTLD in combination with RIS with ORRs of $\sim 70 \%$ and $C R$ rates up to $50 \% .^{70,101,102}$ Specific data on the outcome and survival in poly- or monomorphic types under rituximab are lacking.

In a multicenter phase II trial conducted by Oertel et al, ${ }^{103}$ rituximab $375 \mathrm{mg} / \mathrm{m}^{2}$ weekly, for 4 weeks consecutively, was administered in patients with PTLD after SOT. Fourteen patients have had monomorphic and three have had polymorphic PTLD. CR was induced in up to $50 \%$ of patients. ${ }^{103} \mathrm{~A}$ similar prospective phase II study conducted by Choquet et al ${ }^{104}$ 
showed an ORR of $44.2 \%$ with CR of $28 \%$ in patients with PTLD after SOT. Relapse occurred in $21 \%$ of cases. ${ }^{104}$

A scoring system has also been proposed to identify patients with PTLD who may not respond well to RIS in combination with rituximab. The factors taken in account were age $>60$ years, ECOG performance status $2-4$, and raised LDH. Three risk categories were identified: low-risk group (0 risk factors), intermediate-risk group (1 risk factor), and high-risk group with $>1$ risk factor and the 1- and 2-year survival was $100 \%$ and $79 \%, 36 \%$ and $88 \%, 50 \%$ and $0 \%$, respectively. ${ }^{101}$

In a prospective phase II study, extended treatment with another course of four times weekly rituximab was performed in patients who did not achieve CR after the first course of rituximab. Higher rates of CR were achieved, without increasing toxicity, achieving an intention to treat CR rate of $60.5 \%$ and an overall survival of 42 months. ${ }^{105}$

Thus, rituximab is an effective first-line therapy in CD20positive B-cell PTLD with manageable toxicity and can be incorporated in treatment of polymorphic or monomorphic PTLD independent of comorbidities and performance status.

\section{Combined immunochemotherapy}

Patients with monomorphic PTLD can be treated with polychemotherapy. For polymorphic PTLD with high tumor burden, chemotherapy should also be considered. As TRM of polychemotherapy is high in PTLD patients after HSCT or SOT, ranging between $11 \%$ and $33 \%$, organ function and comorbidities should be assessed as mentioned earlier to outweigh the benefits and risks of chemotherapy. ${ }^{106-108}$

Most experience exists using CHOP-21 (cyclophosphamide, doxorubicin, vincristine, and prednisolone in 21-day intervals) with CR rates of $42 \%-66 \% .^{107-109}$ These response rates can still be achieved in patients refractory to or relapsing after rituximab. ${ }^{101}$

Trappe et al $^{106}$ published the results of a prospective multicenter phase II study ( $\mathrm{N}=74 ; \mathrm{N}=70$ evaluable). The sequential immunochemotherapy, consisting of weekly rituximab 375 $\mathrm{mg} / \mathrm{m}^{2}, 4$ weeks, followed by four cycles of chemotherapy (CHOP-21 regimen with posttherapeutic G-CSF support) in patients who failed initial RIS and who were eligible for more aggressive chemotherapy. PTLD was of late type in $76 \%$ of cases, monomorphic in $96 \%$ of cases, and EBV associated in $44 \%$ of cases. ORR with rituximab was $60 \%$ and improved to $90 \%$ (CR 67\%) after receiving subsequent chemotherapy. Approximately $50 \%$ of responders were progression free after 5 years. Under aggressive antimicrobial prophylaxis, the TRM rate was still $10.6 \%$. The study has been revised introducing risk-stratified sequential treatment according to the response to rituximab. Patients were stratified in two categories: those with low risk, defined as achieving CR after four cycles of rituximab alone and those with high risk, defined as nonCR after rituximab. Low-risk patients received consolidation therapy with another four cycles of rituximab, whereas high-risk patients proceeded to chemotherapy.

This approach is viewed from many experts as evidencebased standard for CD20-positive B-cell PTLD progressive after RIS outside a clinical trial and independent of EBV status. ${ }^{93,106,110}$

\section{Adoptive immunotherapy}

As mentioned earlier, several small studies showed a beneficial effect of EBV-CTLs used for prevention of PTLD in high-risk patient.

The therapeutic effect of these EBV-CTLs was evaluated in one prospective multicenter phase II study. ${ }^{111}$ The majority of patients were post-SOT (95\%); all of them received various prior therapies (rituximab, chemotherapy, and antiviral) and failed to respond. After infusion of cytotoxic T-cells, the ORR was $52 \%$ with $42 \%$ CR. OS was found to be $79 \%$ at 6 months. ${ }^{111,112}$ An advantage of this treatment modality is avoidance of augmenting the risk of graft rejection after RIS in SOT patients. However, treatment is hampered by the complex preparation process, which is not available in all centers.

Donor lymphocyte infusion may also represent a feasible treatment option in patients after HSCT. This approach has shown an ORR of $70 \%$. The availability is much broader than that of EBV-CTLs, but it is not recommended for patients suffering from GvHD. Donor lymphocyte infusion is associated with severe, life-threatening GvHD. ${ }^{64,113,114}$

\section{Surgery}

At present, the value of surgical resection of PTLD is not validated. There are a few situations where surgery is necessary or may have a role as additional treatment modality. First, excision biopsy may be needed if core biopsy is not feasible or its results are nonconclusive and rebiopsy is needed. In this scenario, if the PTLD is localized, a complete removal of lymphoma may be done as a part of the treatment, but adequate systemic therapy according to histology, risk factors, and patient's fitness should also be given. Localized manifestation of PTLD is however very rare, and it seems mostly after SOT such as heart, lung, kidney, or liver transplant. ${ }^{71,115}$

Second, in emergency situations such as persistent hemorrhage despite conservative management or colonic obstruction, surgery is necessary to stop the bleeding or avert colonic perforation. For localized manifestation of early lesions or 
polymorphic PTLD (Ann Arbor stage I), surgical resection might be an option if RIS is not tolerated. Adjuvant systemic therapy with rituximab, although not evidence based, should be considered in patients with polymorphic PTLD. ${ }^{110}$

\section{Radiotherapy}

This therapeutic approach should be considered additionally to other treatment modalities in special circumstances such as orbital involvement, solitary plasmocytoma-like PTLD, Hodgkin and Hodgkin-like PTLD in stage I, or isolated CNS relapse. ${ }^{110}$ Radiotherapy also plays an important role in some emergency setting (ie, cord compression). Moreover, it can be useful in palliation of symptoms due to local complication of PTLD. ${ }^{116,117}$ The treatment regimen (dose and fractionation) should be similar to the de novo lymphoma protocols. In palliative situation, lower doses should be used. ${ }^{71}$

\section{Special clinical situations}

CD20-negative PTLDs, T-cell PTLDs, and PCNS PTLD should be treated according to their counterparts occurring in immunocompetent patients. ${ }^{88}$ In CD30 T-cell lymphomalike PTLD, brentuximab treatment was reported to be successful. ${ }^{118}$ This approach needs to be evaluated in larger case series of HD- and PTCL-type PTLD.

Of all PTLD cases, PCNS involvement occurs in $\sim 5 \%-15 \%$, much more frequent as the novo PCNS lymphoma. Approximately $80 \%$ of total PCNS PTLD are EBVassociated, and those with early onset is $\sim 100 \%$. PCNS PTLD is distinctly more aggressive than its systemic counterpart. ${ }^{119}$ Evens et a ${ }^{120}$ conducted a retrospective analysis of 84 patients with PCNS PTLD in the postrituximab era. They identified some important prognostic factors such as performance status and LDH and showed that the most predictive factor for survival was response to first-line treatment. ${ }^{120}$ There is no established treatment algorithm for PCNS PTLD. The currently used therapy approach is similar to the de novo PCNS lymphoma. The inconsistent treatment regimens and absence of prospective randomized trials make evaluation of retrospective data difficult. For patients with good performance status, systemic high-dose cytarabin or methotrexate is recommended. For those with poor performance status, whole brain irradiation should be considered. The role of CNS prophylaxis in high-risk PTLD patients is also unclear; therapeutic strategies depend on internal institutional protocols. ${ }^{88}$

\section{Salvage therapy}

For patients with relapsed or refractory PTLD after first-line treatment, no current standard therapy options are available.
Data are based only on case reports and retrospective studies (Table 4). Oertel et al ${ }^{121}$ reported a complete response in five of nine relapsed or refractory PTLD patients treated with carboplatin and etoposide. Two patients died due to treatment-related complications. In this setting, an individual therapy concept based on the histological subtype of PTLD must be considered. As most patients present in poor clinical condition and are prone to infectious complications, the treatment plan should also incorporate these aspects. Patients with late relapse (beyond 2 years after first-line treatment) are retreated with the first-line therapy in our institution. For patients with early relapse, we use the carboplatin/etoposide schema reported by Oertel et al. ${ }^{121}$ In case of fit patients, interdisciplinary consolidation by autologous or allogeneic stem cell transplantation is discussed.

\section{Supportive care}

TRM in patients treated with combined chemotherapy is significant, $50 \%$ being caused by infections. Proper prophylaxis of these infections is a key component in the management of patients with PTLD. The usefulness of G-CSF to prevent febrile neutropenia in patients treated for solid tumors or lymphoma has been confirmed. ${ }^{122,123}$ A primary prophylaxis should therefore be considered in all patients with increased risk for febrile neutropenia. ${ }^{124}$ Antibiotic, antiviral, and antifungal prophylaxis during therapy should be considered according to institutional internal protocols. Special consideration is warranted in cases of chronic viral infections such as hepatitis $\mathrm{B}$ and $\mathrm{C}$ or human immunodeficiency virus. Because of risk of reactivation, patients with hepatitis B virus should receive at least prophylaxis with lamivudine..$^{71,125}$

\section{Conclusion and future perspective}

With worldwide increasing transplantation rates and more effective immunosuppressants, early diagnosis and adequate treatment of PTLD will become more and more relevant. The highly variable clinical presentation and histological picture make diagnosis challenging. A close cooperation of clinicians and pathologists is important for correct diagnosis. The backbone of PTLD treatment is RIS. In CD20-positive PTLD, rituximab leads to improved outcome and therefore is the second cornerstone of treatment. However, despite these advances, mortality rate due to PTLD remains high. This is mostly due to poor performance status of the patients and insufficient options for treatment. Prospective studies testing a risk-adapted sequential treatment approach not only include response to rituximab but also other risk factors such as International Prognostic Index are under way (NCT02042391). Incorporation of 
Table 4 Reported salvage regimen and outcome in patients with PTLD relapsed or refractory to first (immune)chemotherapy

\begin{tabular}{|c|c|c|c|c|c|}
\hline & Transplant setting & PTLD type & Prior therapy & Salvage therapy & Outcome \\
\hline $\begin{array}{l}\text { Malhotra et al }{ }^{127} \\
\mathrm{~N}=\mathrm{l}\end{array}$ & $\begin{array}{l}66 \text { years, male } \\
\text { SOT (heart) } \\
\text { EBV IgG negative } \\
\text { 8-year postTx }\end{array}$ & DLBCL, Ann Arbor IA & $\begin{array}{l}\text { RIS + rituximab }+6 \times \\
\text { R-CHOP + radiation }\end{array}$ & $\begin{array}{l}2 \times \text { R-ICE, } 2 \times \\
\text { R-GemOx and } \\
\text { HD-BEAC }+ \\
\text { autologous SCT }\end{array}$ & $\begin{array}{l}\text { At I7 months: alive, } \\
\text { CR, fully functional } \\
\text { allograft }\end{array}$ \\
\hline \multirow[t]{2}{*}{$\begin{array}{l}\text { Komrokji et al }{ }^{128} \\
\mathrm{~N}=2\end{array}$} & $\begin{array}{l}36 \text { years, male } \\
\text { SOT (kidney-pancreas) } \\
\text { EBV IgG positive } \\
\text { OKT3 } \\
\text { Tacrolimus, MMF, prednisone } \\
21 \text {-month postTx }\end{array}$ & CNS PTLD, DLBCL & $\begin{array}{l}\text { ISA: sirolimus + prednisone } \\
R+2 \times \text { ESHAP }+2 \times \text { HD- } \\
\text { MTX }\end{array}$ & $\begin{array}{l}\text { Mini BEAM + } \\
\text { autologous SCT + } \\
\text { radiation }\end{array}$ & $\begin{array}{l}\text { At } 30 \text { months: alive, } \\
\text { CR, fully functional } \\
\text { allograft }\end{array}$ \\
\hline & $\begin{array}{l}52 \text { years, male } \\
\text { SOT ( } 2 \text { nd kidney) } \\
\text { EBV lgG positive } \\
\text { Tacrolimus, MMF, prednisone } \\
\text { II-month postTx }\end{array}$ & $\begin{array}{l}\text { Anaplastic } \\
\text { plasmocytoma }\end{array}$ & $\begin{array}{l}\text { ISA: sirolimus + prednisone } \\
4 \times \mathrm{R} \text { weekly }+3 \times \text { ESHAP }\end{array}$ & $\begin{array}{l}2 \times \text { Mini BEAM }+ \\
\text { autologous SCT }\end{array}$ & $\begin{array}{l}\text { At } 3 \text { I months: alive, } \\
\text { CR, fully functional } \\
\text { allograft }\end{array}$ \\
\hline \multirow[t]{9}{*}{$N=9$} & $\begin{array}{l}59 \text { years, male } \\
\text { SOT (heart) }\end{array}$ & DLCBL, Ann Arbor IV & $\mathrm{RIS}+2 \times \mathrm{CHOP}$ & $4 \times C E$ & $\begin{array}{l}\text { At } 92 \text { months: death } \\
\text { not due to PTLD }\end{array}$ \\
\hline & $\begin{array}{l}38 \text { years, female } \\
\text { SOT (double lung) }\end{array}$ & DLBCL, Ann Arbor IV & $\mathrm{RIS}+\mathrm{I} \times \mathrm{CHOP}$ & $\mathrm{I} \times \mathrm{CE}$ & $\begin{array}{l}\text { Death due to intestine } \\
\text { perforation, PTLD } \\
\text { in PR }\end{array}$ \\
\hline & $\begin{array}{l}59 \text { years, male } \\
\text { SOT (heart) }\end{array}$ & $\begin{array}{l}\text { DLBCL, Ann Arbor } \\
\text { IVE }\end{array}$ & $\mathrm{RIS}+3 \times \mathrm{CHOP}$ & $4 \times C E$ & $\begin{array}{l}\text { At } 17 \text { months: death } \\
\text { not due to PTLD }\end{array}$ \\
\hline & $\begin{array}{l}43 \text { years, female } \\
\text { SOT (lung) }\end{array}$ & DLBCL, Ann Arbor IV & $\mathrm{RIS}+4 \times \mathrm{CHOP}$ & $3 \times \mathrm{CE}$ & $\begin{array}{l}\text { Death due to MOF, } \\
\text { autopsy: CR }\end{array}$ \\
\hline & $\begin{array}{l}65 \text { years, male } \\
\text { SOT (lung) }\end{array}$ & DLBCL, Ann Arbor IV & $6 \times \mathrm{CHOP}$ & $\begin{array}{l}4 \times C E+\text { intrathecal } \\
M T X+\text { cranial } \\
\text { radiation }\end{array}$ & At 55 months: alive, $C R$ \\
\hline & $\begin{array}{l}46 \text { years, female } \\
\text { SOT (lung) }\end{array}$ & DLBCL, Ann Arbor II & $\mathrm{RIS}+3 \times \mathrm{CHOP}$ & $4 \times C E$ & At 39 months: alive, $C R$ \\
\hline & $\begin{array}{l}62 \text { years, male } \\
\text { SOT (heart, renal) }\end{array}$ & MCL, Ann Arbor IV & $\mathrm{RIS}+2 \times \mathrm{CHOP}$ & $2 \times C E$ & Death due to PTLD \\
\hline & $\begin{array}{l}53 \text { years, female } \\
\text { SOT (heart) }\end{array}$ & DLBCL, Ann Arbor IV & $\begin{array}{l}\mathrm{RIS}+3 \times \mathrm{CHOP}+\mathrm{I} \times \\
\mathrm{CBCDA} / \mathrm{VPI}\end{array}$ & $\mathrm{I} \times \mathrm{CE}$ & Death due to PTLD \\
\hline & $\begin{array}{l}40 \text { years, female } \\
\text { SOT (heart) }\end{array}$ & $\begin{array}{l}\text { Atypical Burkitt, Ann } \\
\text { Arbor IIB }\end{array}$ & $\mathrm{RIS}+4 \times \mathrm{R}+6 \times \mathrm{CHOP}$ & $\begin{array}{l}2 \times C E+ \\
\text { abdominal radiation }\end{array}$ & At 9 months: alive, $C R$ \\
\hline \multirow[t]{2}{*}{$\begin{array}{l}\text { Trappe et } \text { al }^{101} \\
\mathrm{~N}=2\end{array}$} & $\begin{array}{l}44 \text { years, female } \\
\text { SOT (liver) } \\
\text { 2.3-month postTx }\end{array}$ & MZL, Ann Arbor IV E & $6 \times \mathrm{R}+\mathrm{I} \times \mathrm{CHOP}$ & $\begin{array}{l}\text { Leukeran }(16 \\
\text { months) }+6 \times \\
\text { bendamustin }\end{array}$ & Death due to PTLD \\
\hline & $\begin{array}{l}45 \text { years, female } \\
\text { SOT (heart) } \\
\text { 12.5-month potsTx }\end{array}$ & DLBCL, Ann Arbor II & $4 \times \mathrm{R}+\mathrm{I} \times \mathrm{CHOP}$ & Ixoten (2 months) & Death due to PTLD \\
\hline Dierickx et al ${ }^{82,88}$ & $\begin{array}{l}36 \text { years, female } \\
\text { SOT ( } 2 \text { nd kidney) } \\
\text { I2-year postTx }\end{array}$ & $\begin{array}{l}\text { EBV-DLBCL, Ann } \\
\text { Arbor IVA }\end{array}$ & $\mathrm{RIS}+\mathrm{R}+\mathrm{R}-\mathrm{CHOP}$ & $\begin{array}{l}\text { R-DHAP + HD- } \\
\text { CTX + autologous } \\
\text { SCT }\end{array}$ & $\begin{array}{l}\text { At } 36 \text { months: alive, } \\
\text { CR, fully functional } \\
\text { allograft }\end{array}$ \\
\hline
\end{tabular}

Abbreviations: CE, carboplatin/etoposide; R-CHOP, rituximab/cyclophosphamide/doxorubicin/vincristine/prednisolone; CNS, central nervous system; CR, complete remission; CTx, chemotherapy; DHAP, dexamethasone/high-dose cytarabin/cisplatin; DLBCL, diffuse large B-cell lymphoma; EBV, Epstein-Barr virus; HD-CTX, high-dose chemotherapy; HD-BEAM, high-dose carmustin/cytarabine/etoposide/melphalan; R-ICE, rituximab/ifosfamid/carboplatin/etoposide; ISA, immunosuppression adjustment; MOF, multiorgan failure; MZL, marginal zone lymphoma; PTLD, posttransplant lymphoproliferative disease; R, rituximab; RIS, reduction of immunosuppression; SCT, stem cell transplantation; SOT, solid organ transplantation; Tx, transplantation; R-GemOx, rituximab/gemcitabine/oxaliplatin; HD-BEAC, high-dose carmustine, etoposide, cytarabin, cyclophosphamide; ESHAP, etoposide, methylprednisolone, cytarabin, cisplatin; HD-MTX, high-dose methotrexate; CBCDA, carboplatin. 
new, less-toxic therapies such as inhibitors of the mammalian target of rapamycin in treatment algorithms might also help us to improve future treatment and outcome of PTLD. ${ }^{126,127}$

\section{Disclosure}

LPM has received congress registration fees and reimbursement of travel costs from Astellas, Janssen, Sanofi, Gentium, Jazz Pharmaceuticals, and Gilead. He has received honoraria for lectures from Novartis, Celgene, and Pfizer. He has acted as a consultant for Celgene and CTI Life Sciences. KL, CMT, and TW report no conflicts of interest in this work.

\section{References}

1. Morscio J, Dierickx D, Tousseyn T. Molecular pathogenesis of B-cell posttransplant lymphoproliferative disorder: what do we know so far? Clin Dev Immunol. 2013;2013:150835.

2. Choquet S, Varnous S, Deback C, Golmard JL, Leblond V. Adapted treatment of Epstein-Barr virus infection to prevent posttransplant lymphoproliferative disorder after heart transplantation. Am J Transplant. 2014;14(4):857-866.

3. Rastelli J, Homig-Holzel C, Seagal J, Muller W, Hermann AC, Rajewsky K, Zimber-Strobl U. LMP1 signaling can replace CD40 signaling in $\mathrm{B}$ cells in vivo and has unique features of inducing class-switch recombination to IgG1. Blood. 2008;111(3):1448-1455.

4. Petrara MR, Giunco S, Serraino D, Dolcetti R, De Rossi A. Posttransplant lymphoproliferative disorders: from epidemiology to pathogenesis-driven treatment. Cancer Lett. 2015;369(1):37-44.

5. Luskin MR, Heil DS, Tan KS, et al. The impact of EBV status on characteristics and outcomes of posttransplantation lymphoproliferative disorder. Am J Transplant. 2015;15(10):2665-2673.

6. Shimizu N, Tanabe-Tochikura A, Kuroiwa Y, Takada K. Isolation of Epstein-Barr virus (EBV)-negative cell clones from the EBV-positive Burkitt's lymphoma (BL) line Akata: malignant phenotypes of BL cells are dependent on EBV. J Virol. 1994;68(9):6069-6073.

7. Ambinder RF. Gammaherpesviruses and "hit-and-run" oncogenesis. Am J Pathol. 2000;156(1):1-3.

8. Capello D, Rossi D, Gaidano G. Post-transplant lymphoproliferative disorders: molecular basis of disease histogenesis and pathogenesis. Hematol Oncol. 2005;23(2):61-67.

9. Rinaldi A, Capello D, Scandurra M, et al. Single nucleotide polymorphism-arrays provide new insights in the pathogenesis of post-transplant diffuse large B-cell lymphoma. Br J Haematol. 2010;149(4):569-577.

10. Craig FE, Johnson LR, Harvey SAK, et al. Gene expression profiling of Epstein-Barr virus-positive and -negative monomorphic B-cell posttransplant lymphoproliferative disorders. Diagn Mol Pathol. 2007;16(3):158-168.

11. Morscio J, Dierickx D, Ferreiro JF, et al. Gene expression profiling reveals clear differences between EBV-positive and EBV-negative posttransplant lymphoproliferative disorders. Am J Transplant. 2013;13(5):1305-1316

12. Djokic M, Le Beau MM, Swinnen LJ, Smith SM, Rubin CM, Anastasi J, Carlson KM. Post-transplant lymphoproliferative disorder subtypes correlate with different recurring chromosomal abnormalities. Genes Chromosomes Cancer. 2006;45(3):313-318.

13. Poirel HA, Bernheim A, Schneider A, et al. Characteristic pattern of chromosomal imbalances in posttransplantation lymphoproliferative disorders: correlation with histopathological subcategories and EBV status. Transplantation. 2005;80(2):176-184.

14. Rinaldi A, Kwee I, Poretti G, et al. Comparative genome-wide profiling of post-transplant lymphoproliferative disorders and diffuse large B-cell lymphomas. Br J Haematol. 2006;134(1):27-36.
15. Vakiani E, Nandula SV, Subramaniyam S, Keller CE, Alobeid B, Murty VV, Bhagat G. Cytogenetic analysis of B-cell posttransplant lymphoproliferations validates the World Health Organization classification and suggests inclusion of florid follicular hyperplasia as a precursor lesion. Hum Pathol. 2007;38(2):315-325.

16. Vakiani E, Basso K, Klein U, et al. Genetic and phenotypic analysis of B-cell post-transplant lymphoproliferative disorders provides insights into disease biology. Hematol Oncol. 2008;26(4):199-211.

17. Cerri M, Capello D, Muti G, et al. Aberrant somatic hypermutation in post-transplant lymphoproliferative disorders. Br J Haematol. 2004;127(3):362-364.

18. Rossi D, Gaidano G, Gloghini A, et al. Frequent aberrant promoter hypermethylation of O6-methylguanine-DNA methyltransferase and death-associated protein kinase genes in immunodeficiency-related lymphomas. Br J Haematol. 2003;123(3):475-478.

19. Herreman A, Dierickx D, Morscio J, et al. Clinicopathological characteristics of posttransplant lymphoproliferative disorders of T-cell origin: single-center series of nine cases and meta-analysis of 147 reported cases. Leuk Lymphoma. 2013;54(10):2190-2199.

20. Kaleem Z, Hassan A, Pathan MH, White G. Flow cytometric evaluation of posttransplant B-cell lymphoproliferative disorders. Arch Pathol Lab Med. 2004;128(2):181-186.

21. Weissmann DJ, Ferry JA, Harris NL, Louis DN, Delmonico F, Spiro I. Posttransplantation lymphoproliferative disorders in solid organ recipients are predominantly aggressive tumors of host origin. Am J Clin Pathol. 1995;103(6):748-755.

22. Heslop HE. How I treat EBV lymphoproliferation. Blood. 2009;114(19): 4002-4008.

23. Swerdlow SH, Campo E, Harris NL, et al. Post-transplant lymphoproliferative disorders (PTLD). In: WHO Classification of Tumours of Haematopoietic and Lymphoid Tissue. 2008:343-350.

24. Bakker NA, Van Imhoff GW, Verschuuren EAM, Van Son WJ. Presentation and early detection of post-transplant lymphoproliferative disorder after solid organ transplantation. Transpl Int. 2007;20(3): 207-218.

25. Schubert S, Abdul-Khaliq H, Lehmkuhl HB, et al. Diagnosis and treatment of post-transplantation lymphoproliferative disorder in pediatric heart transplant patients. Pediatr Transplant. 2009;13(1):54-62.

26. Krishnamurthy S, Hassan A, Frater JL, Paessler ME, Kreisel FM. Pathologic and clinical features of Hodgkin lymphoma - like posttransplant lymphoproliferative disease. Int J Surg Pathol. 2010;18(4):278-285.

27. Tsao L, Hsi ED. The clinicopathologic spectrum of posttransplantation lymphoproliferative disorders. Arch Pathol Lab Med. 2007;131(8):1209-1218.

28. Rohr JC, Wagner HJ, Lauten M, et al. Differentiation of EBVinduced post-transplant Hodgkin lymphoma from Hodgkin-like post-transplant lymphoproliferative disease. Pediatr Transplant. 2008;12(4):426-431.

29. Baker KS, DeFor TE, Burns LJ, Ramsay NK, Neglia JP, Robison LL. New malignancies after blood or marrow stem-cell transplantation in children and adults: incidence and risk factors. J Clin Oncol. 2003;21(7):1352-1358.

30. Curtis RE, Travis LB, Rowlings PA, et al. Risk of lymphoproliferative disorders after bone marrow transplantation: a multi-institutional study. Blood. 1999;94(7):2208-2216.

31. Landgren O, Gilbert ES, Rizzo JD, et al. Risk factors for lymphoproliferative disorders after allogeneic hematopoietic cell transplantation. Blood. 2009;113(20):4992-5001.

32. Doycheva I, Amer S, Watt KD. De novo malignancies after transplantation: risk and surveillance strategies. Med Clin North Am. 2016;100(3):551-567.

33. Euvrard S, Kanitakis J, Claudy A. Skin cancers after organ transplantation. N Engl J Med. 2003;348(17):1681-1691.

34. Mihalov ML, Gattuso P, Abraham K, Holmes EW, Reddy V. Incidence of post-transplant malignancy among 674 solid-organ-transplant recipients at a single center. Clin Transplant. 1996;10(3):248-255. 
35. Organ Procurement and Transplantation Network (OPTN) and the Scientific Registry of Transplant Recipient. Annual Data Report. Department of Health and Human Services, Health Resources and Services Administration, HealthCare Systems Bureau, Division of Transplantation. Am J Transplant. 2010;12:1-156.

36. Cockfield SM. Identifying the patient at risk for post-transplant lymphoproliferative disorder. Transplant Infect Dis. 2001;3(2): $70-78$.

37. Opelz G, Dohler B. Lymphomas after solid organ transplantation: a collaborative transplant study report. Am J Transplant. 2004;4(2): 222-230.

38. Lange A, Klimczak A, Dlubek D, Dybko J. B-cell lymphoproliferative syndrome and peripheral blood CD20+ cells expansion after hematopoietic stem cell transplantation: association with fludarabine and anti-thymocyte globulin containing conditioning regimen. Transplant Proc. 2003;35(8):3093-3095.

39. Schubert S, Renner C, Hammer M, et al. Relationship of immunosuppression to Epstein-Barr viral load and lymphoproliferative disease in pediatric heart transplant patients. J Heart Lung Transplant. 2008;27(1):100-105.

40. Caillard S, Dharnidharka V, Agodoa L, Bohen E, Abbott K. Posttransplant lymphoproliferative disorders after renal transplantation in the United States in era of modern immunosuppression. Transplantation. 2005;80(9):1233-1243.

41. Duvoux C, Pageaux GP, Vanlemmens C, et al. Risk factors for lymphoproliferative disorders after liver transplantation in adults: an analysis of 480 patients. Transplantation. 2002;74(8):1103-1109.

42. Opelz G, Naujokat C, Daniel V, Terness P, Dohler B. Disassociation between risk of graft loss and risk of non-Hodgkin lymphoma with induction agents in renal transplant recipients. Transplantation. 2006; 81(9):1227-1233.

43. Kirk AD, Cherikh WS, Ring M, et al. Dissociation of depletional induction and posttransplant lymphoproliferative disease in kidney recipients treated with alemtuzumab. Am J Transplant. 2007;7(11):2619-2625.

44. Shyu S, Dew MA, Pilewski JM, et al. Five-year outcomes with alemtuzumab induction after lung transplantation. J Heart Lung Transplant. 2011;30(7):743-754.

45. Cao S, Cox KL, Berquist W, et al. Long-term outcomes in pediatric liver recipients: comparison between cyclosporin A and tacrolimus. Pediatr Transplant. 1999;3(1):22-26.

46. Funch DP, Ko HH, Travasso J, Brady J, Kew CE 2nd, Nalesnik MA, Walker AM. Posttransplant lymphoproliferative disorder among renal transplant patients in relation to the use of mycophenolate mofetil. Transplantation. 2005;80(9):1174-1180.

47. Dharnidharka VR, Ho PL, Stablein DM, Harmon WE, Tejani AH. Mycophenolate, tacrolimus and post-transplant lymphoproliferative disorder: a report of the North American Pediatric Renal Transplant Cooperative Study. Pediatr Transplant. 2002;6(5):396-399.

48. Krams SM, Martinez OM. Epstein-Barr virus, rapamycin, and host immune responses. Curr Opin Organ Transplant. 2008;13(6):563-568.

49. Majewski M, Korecka M, Kossev P, et al. The immunosuppressive macrolide RAD inhibits growth of human Epstein-Barr virus-transformed B lymphocytes in vitro and in vivo: a potential approach to prevention and treatment of posttransplant lymphoproliferative disorders. Proc Natl Acad Sci U S A. 2000;97(8):4285-4290.

50. Hess G, Herbrecht R, Romaguera J, et al. Phase III study to evaluate temsirolimus compared with investigator's choice therapy for the treatment of relapsed or refractory mantle cell lymphoma. J Clin Oncol. 2009;27(23):3822-3829.

51. Wheless SA, Gulley ML, Raab-Traub N, McNeillie P, Neuringer IP, Ford HJ, Aris RM. Post-transplantation lymphoproliferative disease: Epstein-Barr virus DNA levels, HLA-A3, and survival. Am J Respir Crit Care Med. 2008;178(10):1060-1065.

52. Reddy N, Rezvani K, Barrett AJ, Savani BN. Strategies to prevent EBV reactivation and posttransplant lymphoproliferative disorders (PTLD) after allogeneic stem cell transplantation in high-risk patients. Biol Blood Marrow Transplant. 2011;17(5):591-597.
53. Sundin M, Le Blanc K, Ringden O, et al. The role of HLA mismatch, splenectomy and recipient Epstein-Barr virus seronegativity as risk factors in post-transplant lymphoproliferative disorder following allogeneic hematopoietic stem cell transplantation. Haematologica. 2006;91(8):1059-1067.

54. Kinch A, Sundstrom C, Tufveson G, Glimelius I. Association between HLA-A1 and -A2 types and Epstein-Barr virus status of post-transplant lymphoproliferative disorder. Leuk Lymphoma. 2016;57(10):1-8.

55. Paranjothi S, Yusen RD, Kraus MD, Lynch JP, Patterson GA, Trulock EP. Lymphoproliferative disease after lung transplantation: comparison of presentation and outcome of early and late cases. J Heart Lung Transplant. 2001;20(10):1054-1063.

56. Kew CE 2nd, Lopez-Ben R, Smith JK, et al. Postransplant lymphoproliferative disorder localized near the allograft in renal transplantation. Transplantation. 2000;69(5):809-814.

57. Reams BD, McAdams HP, Howell DN, Steele MP, Davis RD, Palmer SM. Posttransplant lymphoproliferative disorder: incidence, presentation, and response to treatment in lung transplant recipients. Chest. 2003;124(4):1242-1249.

58. Claudon M, Kessler M, Champigneulle J, Lefevre F, Hestin D, Renoult E. Lymphoproliferative disorders after renal transplantation: role of medical imaging. Eur Radiol. 1998;8(9):1686-1693.

59. Weber T, Wickenhauser C, Monecke A, et al. Treatment of rare co-occurrence of Epstein-Barr virus-driven post-transplant lymphoproliferative disorder and hemophagocytic lymphohistiocytosis after allogeneic stem cell transplantation. Transpl Infect Dis. 2014;16(6):988-992.

60. Phan TG, O’Neill BP, Kurtin PJ. Posttransplant primary CNS lymphoma. Neuro Oncol. 2000;2(4):229-238.

61. Penn I, Porat G. Central nervous system lymphomas in organ allograft recipients. Transplantation. 1995;59(2):240-244.

62. Lemoine A, Pham P, Azoulay D, et al. Detection of gammopathy by serum protein electrophoresis for predicting and managing therapy of lymphoproliferative disorder in 911 recipients of liver transplants. Blood. 2001;98(5):1332-1338.

63. Wagner HJ, Wessel M, Jabs W, Smets F, Fischer L, Offner G, Bucsky P. Patients at risk for development of posttransplant lymphoproliferative disorder: plasma versus peripheral blood mononuclear cells as material for quantification of Epstein-Barr viral load by using real-time quantitative polymerase chain reaction. Transplantation. 2001;72(6):1012-1019.

64. Styczynski J, Einsele H, Gil L, Ljungman P. Outcome of treatment of Epstein-Barr virus-related post-transplant lymphoproliferative disorder in hematopoietic stem cell recipients: a comprehensive review of reported cases. Transpl Infect Dis. 2009;11(5):383-392.

65. Green M, Bueno J, Rowe D, Mazariegos G, Qu L, Abu-Almagd K, Reyes J. Predictive negative value of persistent low Epstein-Barr virus viral load after intestinal transplantation in children. Transplantation. 2000;70(4):593-596.

66. Sirvent-Von Bueltzingsloewen A, Morand P, Buisson M, Souillet G, Chambost H, Bosson JL, Bordigoni P. A prospective study of EpsteinBarr virus load in 85 hematopoietic stem cell transplants. Bone Marrow Transplant. 2002;29(1):21-28.

67. Aalto SM, Juvonen E, Tarkkanen J, et al. Lymphoproliferative disease after allogeneic stem cell transplantation - pre-emptive diagnosis by quantification of Epstein-Barr virus DNA in serum. J Clin Virol. 2003;28(3):275-283.

68. Kinch A, Oberg G, Arvidson J, Falk KI, Linde A, Pauksens K. Posttransplant lymphoproliferative disease and other Epstein-Barr virus diseases in allogeneic haematopoietic stem cell transplantation after introduction of monitoring of viral load by polymerase chain reaction. Scand J Infect Dis. 2007;39(3):235-244.

69. Gulley ML, Tang W. Using Epstein-Barr viral load assays to diagnose, monitor, and prevent posttransplant lymphoproliferative disorder. Clin Microbiol Rev. 2010;23(2):350-366.

70. Yang J, Tao Q, Flinn IW, et al. Characterization of Epstein-Barr virusinfected B cells in patients with posttransplantation lymphoproliferative disease: disappearance after rituximab therapy does not predict clinical response. Blood. 2000;96(13):4055-4063. 
71. Parker A, Bowles K, Bradley JA, et al. Management of post-transplant lymphoproliferative disorder in adult solid organ transplant recipients - BCSH and BTS guidelines. Br J Haematol. 2010;149(5):693-705.

72. Gil L, Styczynski J, Komarnicki M. Strategy of pre-emptive management of Epstein-Barr virus post-transplant lymphoproliferative disorder after stem cell transplantation: results of European transplant centers survey. Contemp Oncol (Pozn). 2012;16(4):338-340.

73. Heslop HE. Biology and treatment of Epstein-Barr virus-associated non-Hodgkin lymphomas. Hematology Am Soc Hematol Educ Program. 2005:260-266.

74. Merlo A, Turrini R, Dolcetti R, Martorelli D, Muraro E, Comoli P, Rosato A. The interplay between Epstein-Barr virus and the immune system: a rationale for adoptive cell therapy of EBV-related disorders. Haematologica. 2010;95(10):1769-1777.

75. Heslop HE, Slobod KS, Pule MA, et al. Long-term outcome of EBVspecific T-cell infusions to prevent or treat EBV-related lymphoproliferative disease in transplant recipients. Blood. 2010;115(5):925-935.

76. Savoldo B, Goss JA, Hammer MM, et al. Treatment of solid organ transplant recipients with autologous Epstein Barr virus-specific cytotoxic T lymphocytes (CTLs). Blood. 2006;108(9):2942-2949.

77. Comoli $\mathrm{P}$, Labirio $\mathrm{M}$, Basso $\mathrm{S}$, et al. Infusion of autologous Epstein-Barr virus (EBV)-specific cytotoxic T cells for prevention of EBV-related lymphoproliferative disorder in solid organ transplant recipients with evidence of active virus replication. Blood. 2002;99(7):2592-2598.

78. Rooney CM, Smith CA, Ng CY, et al. Infusion of cytotoxic T cells for the prevention and treatment of Epstein-Barr virus-induced lymphoma in allogeneic transplant recipients. Blood. 1998;92(5):1549-1555.

79. Vickers MA, Wilkie GM, Robinson N, et al. Establishment and operation of a good manufacturing practice-compliant allogeneic Epstein-Barr virus (EBV)-specific cytotoxic cell bank for the treatment of EBV-associated lymphoproliferative disease. Br J Haematol. 2014;167(3):402-410.

80. Leen AM, Bollard CM, Mendizabal AM, et al. Multicenter study of banked third-party virus-specific $\mathrm{T}$ cells to treat severe viral infections after hematopoietic stem cell transplantation. Blood. 2013;121(26):5113-5123.

81. Zimmermann H, Trappe RU. Therapeutic options in post-transplant lymphoproliferative disorders. Ther Adv Hematol. 2011;2(6):393-407.

82. Network NCC. Non-Hodgkin's Lymphomas (Version 2.2016). Available from: http://www.nccn.org/professionals/physician_gls/pdf/nhl. pdf. Accessed February 13, 2016.

83. Harris NL, Ferry JA, Swerdlow SH. Posttransplant lymphoproliferative disorders: summary of Society for Hematopathology Workshop. Semin Diagn Pathol. 1997;14(1):8-14.

84. Stuhlmann-Laeisz C, Oschlies I, Klapper W. Detection of EBV in reactive and neoplastic lymphoproliferations in adults-when and how? $J$ Hematop. 2014;7(4):165-170.

85. Cheson BD, Fisher RI, Barrington SF, Cavalli F, Schwartz LH, Zucca E, Lister TA. Recommendations for initial evaluation, staging, and response assessment of Hodgkin and non-Hodgkin lymphoma: the Lugano classification. J Clin Oncol. 2014;32(27):3059-3068.

86. Barrington SF, Mikhaeel NG, Kostakoglu L, et al. Role of imaging in the staging and response assessment of lymphoma: consensus of the International Conference on Malignant Lymphomas Imaging Working Group. J Clin Oncol. 2014;32(27):3048-3058.

87. Dierickx D, Tousseyn T, Requile A, et al. The accuracy of positron emission tomography in the detection of posttransplant lymphoproliferative disorder. Haematologica. 2013;98(5):771-775.

88. Dierickx D, Tousseyn T, Gheysens O. How I treat posttransplant lymphoproliferative disorders. Blood. 2015;126(20):2274-2283.

89. Sorror ML. Comorbidities and hematopoietic cell transplantation outcomes. Hematology Am Soc Hematol Educ Program. 2010;2010: 237-247.

90. A predictive model for aggressive non-Hodgkin's lymphoma. The International Non-Hodgkin's Lymphoma Prognostic Factors Project. N Engl J Med. 1993;329(14):987-994.
91. Trappe RU, Choquet S, Dierickx D, et al. International prognostic index, type of transplant and response to rituximab are key parameters to tailor treatment in adults with CD20-positive B cell PTLD: clues from the PTLD-1 trial. Am J Transplant. 2015;15(4):1091-1100.

92. Dierickx D, Tousseyn T, Morscio J, Fieuws S, Verhoef G. Validation of prognostic scores in post-transplantation lymphoproliferative disorders. J Clin Oncol. 2013;31(27):3443-3444.

93. Podoltsev N, Zhang B, Yao X, Bustillo I, Deng Y, Cooper DL. Chemoimmunotherapy and withdrawal of immunosuppression for monomorphic posttransplant lymphoproliferative disorders. Clin Lymphoma Myeloma Leuk. 2013;13(6):716-720.

94. Styczynski J, Gil L, Tridello G, et al. Response to rituximab-based therapy and risk factor analysis in Epstein Barr Virus-related lymphoproliferative disorder after hematopoietic stem cell transplant in children and adults: a study from the Infectious Diseases Working Party of the European Group for Blood and Marrow Transplantation. Clin Infect Dis. 2013;57(6):794-802.

95. Evens AM, David KA, Helenowski I, et al. Multicenter analysis of 80 solid organ transplantation recipients with post-transplantation lymphoproliferative disease: outcomes and prognostic factors in the modern era. J Clin Oncol. 2010;28(6):1038-1046.

96. Jacobson CA, LaCasce AS. Lymphoma: risk and response after solid organ transplant. Oncology (Williston Park). 2010;24(10):936-944.

97. Tsai DE, Hardy CL, Tomaszewski JE, et al. Reduction in immunosuppression as initial therapy for posttransplant lymphoproliferative disorder: analysis of prognostic variables and long-term follow-up of 42 adult patients. Transplantation. 2001;71(8):1076-1088.

98. Reshef R, Vardhanabhuti S, Luskin MR, et al. Reduction of immunosuppression as initial therapy for posttransplantation lymphoproliferative disorder (bigstar). Am J Transplant. 2011;11(2):336-347.

99. Swinnen LJ, LeBlanc M, Grogan TM, et al. Prospective study of sequential reduction in immunosuppression, interferon alpha- $2 \mathrm{~B}$, and chemotherapy for posttransplantation lymphoproliferative disorder. Transplantation. 2008;86(2):215-222.

100. Allen U, Hebert D, Moore D, Dror Y, Wasfy S. Epstein-Barr virusrelated post-transplant lymphoproliferative disease in solid organ transplant recipients, 1988-97: a Canadian multi-centre experience. Pediatr Transplant. 2001;5(3):198-203.

101. Trappe RU, Choquet S, Reinke P, et al. Salvage therapy for relapsed posttransplant lymphoproliferative disorders (PTLD) with a second progression of PTLD after Upfront chemotherapy: the role of singleagent rituximab. Transplantation. 2007;84(12):1708-1712.

102. Elstrom RL, Andreadis C, Aqui NA, et al. Treatment of PTLD with rituximab or chemotherapy. Am J Transplant. 2006;6(3):569-576.

103. Oertel SH, Verschuuren E, Reinke P, et al. Effect of anti-CD 20 antibody rituximab in patients with post-transplant lymphoproliferative disorder (PTLD). Am J Transplant. 2005;5(12):2901-2906.

104. Choquet S, Leblond V, Herbrecht R, et al. Efficacy and safety of rituximab in B-cell post-transplantation lymphoproliferative disorders: results of a prospective multicenter phase 2 study. Blood. 2006;107(8):3053-3057.

105. Gonzalez-Barca E, Domingo-Domenech E, et al. Prospective phase II trial of extended treatment with rituximab in patients with B-cell post-transplant lymphoproliferative disease. Haematologica. 2007;92(11):1489-1494.

106. Trappe R, Oertel S, Leblond V, et al. Sequential treatment with rituximab followed by CHOP chemotherapy in adult B-cell post-transplant lymphoproliferative disorder (PTLD): the prospective international multicentre phase 2 PTLD-1 trial. Lancet Oncol. 2012;13(2):196-206.

107. Mamzer-Bruneel MF, Lome C, Morelon E, et al. Durable remission after aggressive chemotherapy for very late post-kidney transplant lymphoproliferation: a report of 16 cases observed in a single center. $J$ Clin Oncol. 2000;18(21):3622-3632.

108. Choquet S, Trappe R, Leblond V, Jager U, Davi F, Oertel S. CHOP21 for the treatment of post-transplant lymphoproliferative disorders (PTLD) following solid organ transplantation. Haematologica. 2007;92(2):273-274. 
109. Knight JS, Tsodikov A, Cibrik DM, Ross CW, Kaminski MS, Blayney DW. Lymphoma after solid organ transplantation: risk, response to therapy, and survival at a transplantation center. J Clin Oncol. 2009;27(20):3354-3362.

110. Zimmermann H, Trappe RU. EBV and posttransplantation lymphoproliferative disease: what to do? Hematology Am Soc Hematol Educ Program. 2013;2013:95-102.

111. Haque T, Wilkie GM, Jones MM, et al. Allogeneic cytotoxic T-cell therapy for EBV-positive posttransplantation lymphoproliferative disease: results of a phase 2 multicenter clinical trial. Blood. 2007;110(4):1123-1131.

112. Haque T, Wilkie GM, Taylor C, et al. Treatment of Epstein-Barrvirus-positive post-transplantation lymphoproliferative disease with partly HLA-matched allogeneic cytotoxic T cells. Lancet. 2002;360(9331):436-442.

113. Papadopoulos EB, Ladanyi M, Emanuel D, et al. Infusions of donor leukocytes to treat Epstein-Barr virus-associated lymphoproliferative disorders after allogeneic bone marrow transplantation. $N$ Engl J Med. 1994;330(17):1185-1191.

114. Doubrovina E, Oflaz-Sozmen B, Prockop SE, et al. Adoptive immunotherapy with unselected or EBV-specific T cells for biopsy-proven EBV+ lymphomas after allogeneic hematopoietic cell transplantation. Blood. 2012;119(11):2644-2656.

115. Foroncewicz B, Mucha K, Usiekniewicz J, Chmura A, Kryst P, Soldacki D, Paczek L. Posttransplant lymphoproliferative disorder of the lung in a renal transplant recipient treated successfully with surgery. Transplant Proc. 2006;38(1):173-176.

116. Kang SK, Kirkpatrick JP, Halperin EC. Low-dose radiation for posttransplant lymphoproliferative disorder. Am J Clin Oncol. 2003;26(2):210-214.

117. Jaeger G, Linkesch W, Temmel W, Neumeister P. AntiCD20 monoclonal antibody-based radioimmunotherapy of relapsed chemoresistant aggressive post-transplantation B-lymphoproliferative disorder in heart-transplant recipient. Lancet Oncol. 2005;6(8):629-631.

118. Choi M, Fink S, Prasad V, Anagnostopoulos I, Reinke P, Schmitt CA. T cell PTLD successfully treated with single-agent brentuximab vedotin first-line therapy. Transplantation. 2016;100(3):e8-e10.
119. Kempf C, Tinguely M, Rushing EJ. Posttransplant lymphoproliferative disorder of the central nervous system. Pathobiology. 2013;80(6):310-318.

120. Evens AM, Choquet S, Kroll-Desrosiers AR, et al. Primary CNS posttransplant lymphoproliferative disease (PTLD): an international report of 84 cases in the modern era. Am JTransplant. 2013;13(6):1512-1522.

121. Oertel SH, Papp-Vary M, Anagnostopoulos I, Hummel MW, Jonas S, Riess HB. Salvage chemotherapy for refractory or relapsed posttransplant lymphoproliferative disorder in patients after solid organ transplantation with a combination of carboplatin and etoposide. $\mathrm{Br}$ J Haematol. 2003;123(5):830-835.

122. Cooper KL, Madan J, Whyte S, Stevenson MD, Akehurst RL. Granulocyte colony-stimulating factors for febrile neutropenia prophylaxis following chemotherapy: systematic review and meta-analysis. $B M C$ Cancer. 2011;11:404.

123. Kuderer NM. Meta-analysis of randomized controlled trials of granulocyte colony-stimulating factor prophylaxis in adult cancer patients receiving chemotherapy. Cancer Treat Res. 2011;157:127-143.

124. Smith TJ, Bohlke K, Lyman GH, et al. Recommendations for the use of WBC growth factors: American Society of Clinical Oncology clinical practice guideline update. J Clin Oncol. 2015;33(28): 3199-3212.

125. Loomba R, Rowley AK, Wesley R, Smith KG, Liang TJ, Pucino F, Csako G. Hepatitis B immunoglobulin and lamivudine improve hepatitis B-related outcomes after liver transplantation: meta-analysis. Clin Gastroenterol Hepatol. 2008;6(6):696-700.

126. 2010 OPTN/SRTR Annual Data Report. Available from: http://srtr. transplant.hrsa.gov/annual_reports/2010/chapter_index.htm. Accessed December 28, 2015.

127. Malhotra B, Rahal AK, Farhoud H, Moore DF Jr, Kallail KJ. Treatment of recurrent posttransplant lymphoproliferative disorder with autologous blood stem cell transplant. Case Reports Transplant. 2015;2015:801082.

128. Komrokji RS, Oliva JL, Zand M, Felgar R, Abboud CN. Mini-BEAM and autologous hematopoietic stem-cell transplant for treatment of posttransplant lymphoproliferative disorders. Am J Hematol. 2005;79(3): 211-215.
Transplant Research and Risk Management

\section{Publish your work in this journal}

Transplant Research and Risk Management is an international, peerreviewed open access journal focusing on all aspects of transplantation and risk management to achieve optimal outcomes in the recipient improving survival and quality of life. The manuscript management system is completely online and includes a very quick and fair peer-review system,

\section{Dovepress}

which is all easy to use. Visit http://www.dovepress.com/testimonials.php to read real quotes from published authors. 